\title{
A abordagem interdisciplinar no estudo do Homo brasilis: a genética em acordo e desacordo com a história
}

The interdisciplinary approach in the study
of Homo brasilis: genetics in agreement and disagreement with history Renato Pereira Brandão

O registro filogenético da população brasileira autoclassificada como "branca" do Sudeste

Em abril de 2000 foi publicado o artigo "Retrato molecular do Brasil", de autoria do Prof. Sérgio D. J. Pena, titular do Departamento de Bioquímica e Imunologia da Universidade Federal de Minas Gerais, onde estão expressos os resultados da sua pesquisa sobre a origem genética de indivíduos representantes do segmento da população brasileira autoclassificada como branca. A importân-

Renato Pereira Brandão é doutor em História pela Universidade Federal Fluminense e professor titular da Universidade Estácio de Sá - Curso de Relações Internacionais, Rio de Janeiro, Brasil (renatobrand@gmail. com).

Artigo recebido em 27 de junho e aprovado para publicação em 4 de setembro de 2013.

Est. Hist., Rio de Faneiro, vol. 26, no 52, p. 391-408, julho-dezembro de 2013. 


\section{Renato Pereira Brandão}

cia desta pesquisa está não só em comprovar que também este segmento é decorrente de um intenso processo miscigenatório, como em identificar uma expressiva participação do contingente indígena, inclusive na região Sudeste. Assim, os resultados apresentados se contrapõem à versão histórica ainda hoje aceita por muitos e divulgada em obras didáticas, segundo a qual a população nativa do Sudeste teria sido praticamente exterminada ao longo do século XVI, em consequência da ação de conquista colonial empreendida na América Portuguesa.

Após atualização, e tendo a proposta de abordar a historicidade do processo formador da população brasileira por uma ótica interdisciplinar, o artigo de Sérgio Pena foi novamente publicado em 2002 no livro Homo brasilis: aspectos genéticos, linguísticos, históricos e socioantropologicos da formação do povo brasileiro, juntamente com outros trabalhos de áreas acadêmicas diversas.

No estudo da ancestralidade da população brasileira "branca" atual, estabelecida de acordo com o critério de autoclassificação adotado pelo IBGE no Censo de 1991, foram utilizados dois marcadores moleculares de linhagens genealógicas: o cromossoma Y, para estabelecer as linhagens paternas, ou patrilinhagens, e o DNA mitocondrial, para as linhagens maternas, ou matrilinhagens. No estudo da patrilinhagem, foram selecionados 12 grupos (haplogrupos) diferenciados por características específicas presentes no cromossoma Y, exclusivo do sexo masculino e, portanto, transmissível somente de pai para filho. Constatou-se que o haplogrupo dominante na população masculina autoclassificada branca do Brasil é o mesmo dominante na população masculina de Portugal (haplogrupo 1 - $54 \%$ no Brasil e 63,4 \% em Portugal). Por outro lado, o registro do haplogrupo $\mathrm{AF}$ referente às populações africanas subsaarianas, de onde proveio a maior parte dos africanos encaminhados ao Brasil, é inexpressivo, contribuindo com somente $2 \%$ na região Norte e de todo ausente para a região Sudeste. Já o registro do haplogrupo 18 , referido à patrilinhagem indígena, não se encontra presente em nenhum dos genomas analisados.

Quanto ao estudo da matrilinhagem, feito a partir de características presentes no DNA mitocondrial transmitido pela mãe para filhos e filhas, os resultados foram bem diversos. Neste caso, a carga genética de origem europeia tem seu percentual reduzido para $39 \%$, enquanto o de origem africana é de $28 \%$ e o de origem indígena de $33 \%$. No caso da região Sudeste os valores são quase que equitativamente distribuídos em $33 \%, 34 \%$ e $31 \%$, respectivamente.

Segundo Pena (2002: 25-26), "os resultados obtidos demonstram que a imensa maioria (provavelmente mais de 90\%) das patrilinhagens dos brancos brasileiros é de origem europeia, enquanto a maioria (aproximadamente 60\%) das matrilinhagens é de origem ameríndia ou africana". Já a patrilinhagem europeia está representada basicamente pelo português, pois foi constatado não haver diferenças significativas "quando comparamos com testes estatísticos as frequências dos haplogrupos em brasileiros e portugueses" (Idem: 22). 
Tecendo considerações históricas, Pena conclui que os resultados estão de acordo com o que se sabe sobre o povoamento do Brasil Colônia. A patrilinhagem quase que exclusiva portuguesa é devida ao fato de os primeiros imigrantes colonizadores não trazerem mulheres, iniciando um processo de miscigenação com mulheres indígenas, estendido posteriormente às negras (Idem: 27).

Entende assim o autor que os resultados obtidos em seus estudos genéticos vêm corroborar o modelo que considera o português o principal reprodutor masculino, enquanto os contingentes indígenas e africanos quase nada ou, no caso do Sudeste, em nada teriam contribuído para a formação do atual contingente populacional "branco" brasileiro.

Consideramos, contudo, que a transposição de dados de um determinado campo de conhecimento para outro, a fim de construir modelos interpretativos integrados, é um trabalho complexo que exige acuradas discussões entre especialistas das áreas envolvidas. Neste caso, é preciso que os dados filogenéticos sejam confrontados com os contextos sociais e culturais recuperados pela pesquisa histórica.

\section{Fundamentos históricos da questão indígena}

Neste tópico, nosso enfoque se restringe à participação da etnia indígena na formação da população do Sudeste. Devemos inicialmente observar que, ao tratar de um processo miscigenatório ocorrido principalmente nos séculos XVI e XVII, é necessário considerar, de um lado, os recursos materiais e humanos disponíveis à Coroa de Portugal no processo de conquista e povoamento de sua porção territorial do Novo Mundo, e, de outro, os recursos e interesses das sociedades nativas envolvidas nesses primeiros contatos interétnicos com os contingentes colonizadores europeus.

Acreditamos que, acima mesmo do cunho mercantilista, o interesse maior da Coroa de Portugal, no processo de consolidar sua posse na faixa territorial da América Portuguesa, se ligava a razões estratégicas, visando a assegurar o controle da rota de navegação para o Índico via Atlântico Sul. Como essa rota, devido ao regime das correntes marinhas, passava ao longo do litoral Nordeste-Sudeste do Brasil, o efetivo domínio desse litoral se apresentava como imprescindível na arquitetura da rede mercantil ultramarina portuguesa (cf. Brandão, 1999: 81-82).

Por outro lado, a concretização desse projeto estratégico tinha como entrave a escassa disponibilidade de recursos humanos, já que o processo de construção de um vasto e rico império ultramarino oriental absorvia a quase totalidade do contingente populacional masculino disponível no pequeno reino de Portugal. 


\section{Renato Pereira Brandão}

Do ponto de vista da população nativa, naquele momento, grande parte do território da América Portuguesa estava habitado por indígenas da família linguística tupi-guarani, afiliada ao tronco linguístico tupi, de origem amazônica. Esse conjunto étnico nativo se dividia em dois grandes grupos. O guarani, que ocupava as bacias dos rios Paraná, Paraguai e Uruguai, e o tupi do litoral, também conhecido pelo nome genérico de tupinambá, que ocupava, de modo quase que exclusivo, a região litorânea Sudeste-Nordeste. Em oposição à maior parte das sociedades aborígenes americanas, na quase totalidade matrilineares, a linhagem de parentesco tupi-guarani é exclusivamente patrilinear. Ou seja, somente a linhagem paterna era considerada como linha de descendência.

Quando da chegada de Cabral, os indígenas tupi-guarani ocupavam o litoral brasileiro quase que totalmente, estando perfeitamente adaptados ao ambiente costeiro e à exploração dos recursos marinhos, atividade complementada com a prática da agricultura de subsistência. Esse complexo etnolinguístico formava um conjunto social tipicamente tribal, dividido em diversas "nações" de tradição guerreira, como tupiniquim, temiminó, tupinambá, caeté, tamoio, entre outros (Idem: 119-131).

Assim, o desafio maior a ser superado pela Coroa do pequeno reino ibérico, na América, era conquistar e consolidar seu poder sobre uma extensa faixa litorânea, intensamente ocupada por povos nativos, sem contar praticamente com recursos humanos disponíveis para tal conquista.

Sabemos que a Coroa de Portugal superou esse obstáculo e conseguiu consolidar seu poder sobre a faixa litorânea ocidental do Atlântico Sul, mesmo transpondo para cá um contingente militar extremamente reduzido. A nosso ver, isso se explica por ter a Coroa adotado a estratégia de promover a criação de núcleos urbanos coloniais tendo à frente portugueses que não só se instalaram neles como também foram geradores de grandes proles mamelucas. Se a fundação de São Vicente, Salvador e Olinda se deve a João Ramalho, Diogo Álvares Caramuru e Jerônimo de Albuquerque, respectivamente, que se estabeleceram por alianças matrimoniais no seio das "nações" tupi locais, o desenvolvimento desses núcleos urbanos foi obra de seus descendentes mamelucos. A referência patrilinear fazia com que eles fossem considerados portugueses, mesmo que seus antepassados masculinos ibéricos estivessem já distantes por gerações.

Assim, mesmo sendo poucos os portugueses aqui estabelecidos, esse processo fez surgir um número sempre crescente de novos luso-tupis, originados de pais mamelucos e mães nativas. Apesar de serem, tanto na cultura quanto na genética, mais índios que portugueses, esses luso-tupis preservavam, através da patrilinearidade, uma difusa, mas presente, relação de fidelidade com a Coroa. Ao mesmo tempo, o fato de não terem sido estabelecidas na América Portuguesa legislações discriminatórias para esses luso-indígenas possibilitou ao mameluco 
A abordagem interdisciplinar no estudo do Homo brasilis

ocupar em grande parte os espaços sociais reservados ao branco, em razão da quase ausência do europeu nos primeiros tempos coloniais (cf. Brandão, 1991: 156-157).

Um documento bastante curioso que retrata de forma expressiva a dimensão da participação mameluca no Sudeste seiscentista é aquele identificado como Translado do auto que mandou fazer o Dezembargador Manoel Pinto da Rocha Ounidor geral deste Estado pa preguntar testemunhas sobre o caso abaixo declarado, encontrado no códice denominado Livro Primeiro do Governo do Brasil. Nesse documento, datado de 12 de setembro de 1616, encontra-se registrado "que huns mamalucos naturais de Sam Paulo, e moradores no Rio de Janeiro andauaõ em Iglaterra, e os trouxeraõ allj com sinquo naos tres grandes, E duas mais piquenas, (...) que foraõ Ter omde chamaõ Cabo frio, aonde caregaraõ de Pao brazil" (Livro Primeiro do Governo do Brasil, 1958: 147).

Vemos assim que já no início do século XVII havia mamelucos envolvidos em vultosos empreendimentos mercantilistas, inclusive indo à Inglaterra para adquirir embarcações de grande porte. Tomando caminho diverso, os mamelucos do planalto Vicentino foram os principais responsáveis pela expansão territorial da América Portuguesa em direção ao interior do continente.

Este contexto histórico se coaduna, inequivocamente, com o constatado por Pena, referente à carga genética ameríndia na linhagem matrilinear do "branco". O fato de a maior parte das "nações" tupi-guarani estarem extintas já no meado do século XVIII, e do percentual da carga genética ameríndia, no caso do Sudeste, apresentar hoje os mesmos valores para os dois grupos étnicos de origem africana e europeia, que para cá vieram ou foram enviados de forma intensa mais tardiamente, expressa a intensidade da incorporação deste contingente ameríndio à nossa sociedade colonial nos dois primeiros séculos. Deste modo, em relação à matrilinhagem, os dados filogenéticos são realmente corroborados pelos dados históricos.

Quanto à patrilinhagem, Cortesão (1964: 123-142) nos mostra que o contingente masculino destes núcleos estabelecidos por portugueses era formado inicialmente não só por seus filhos mamelucos como também por outros indígenas da mesma "nação" que os acolheu. Silva (1955: 65-66), ao tratar de São Paulo nos tempos coloniais, traça um quadro comum a diversos outros núcleos urbanos contemporâneos. Ele observa que o papel desempenhado pelos índios na colonização do planalto Vicentino foi mais considerável do que à primeira vista possa parecer, destacando sua importância tanto na guerra quanto na vida econômica, o que explicaria o "aumento em proporção cada vez maior, relativamente aos brancos, da população indígena”. Apesar da importância estratégica destes núcleos capitaneados por mamelucos, é evidente que estes não poderiam ser suficientes para a manutenção de um efetivo controle do litoral brasileiro. 


\section{Renato Pereira Brandão}

Assim, a Coroa utilizou, igualmente, da estratégia de cooptação da força guerreira tupi através do assentamento de aldeamentos missionários. No caso do litoral Nordeste-Sudeste, este encargo ficou, quase exclusivamente, por conta da Companhia de Jesus.

Diferindo visceralmente das missões jesuíticas hispânicas, nas quais as comunidades indígenas encontravam-se segregadas da sociedade colonial, nestes aldeamentos estavam associadas a ação catequista com a ação militar, em consonância com a missão da ordem militar que detinha o Padroado no Brasil, a Ordem de Cristo. Deste modo, na capitania do Rio de Janeiro, os aldeamentos jesuíticos foram implantados objetivando, principalmente, a defesa da baía da Guanabara, após a tentativa dos franceses de tomar posse em 1555.

O aldeamento de São Lourenço foi, assim, situado em terras fronteiriças à cidade de S. Sebastião do Rio de Janeiro, formando seus índios a guarnição da fortaleza de Santa Cruz, principal bastião defensor da barra da baía. O aldeamento de São Francisco Xavier foi posicionado de forma defensiva do acesso litorâneo meridional, contrapondo-se ao aldeamento de São Pedro, defensor do acesso setentrional. Os indígenas destes aldeamentos formaram as matrizes populacionais das atuais cidades de Niterói, Itaguaí e São Pedro da Aldeia, respectivamente (cf. Brandão, 2009: 36-41).

A participação indígena masculina se fez presente não só na formação das populações de núcleos urbanos originários de aldeamentos como também na formação da própria cidade do Rio de Janeiro, conforme expresso nas palavras do P. Leonardo do Valle: “(...) a maior parte dos Indios que a armada levou comsigo a povoar o Rio são os nossos discípulos de Piratininga (...) sofreram deixar suas mulheres e filhos e repartirem-se por favorecer a armada, que sem elles mui mal podiam povoar" (apud Navarro, 1988: 476).

Esta participação não ficou restrita ao litoral, mas estendeu-se também na conquista do sertão e do espaço hispânico. Polarizado no planalto Vicentino e desconhecendo o limite estabelecido no Tratado de Tordesilhas, este processo de expansão teve como agente não só o mameluco como o próprio indígena tupi. Assim demonstram diversos documentos jesuíticos hispânicos, onde os vicentinos são identificados como "mamelucos portugueses y tupis de San Pablo". Entre a farta documentação, exemplificamos com a carta do padre Ximenes, datada de 4 de fevereiro de 1635 , em que este informa que os tupis chegam às reduções jesuíticas situadas em território hispânico tanto pelo rio Guaíba como por terra. "Nele [no tupi] confiam os portugueses todos os seus resgates, e de sua casa partem todos os anos as frotas de miseráveis cativos que levam os tupis, por terra" (apud Porto, 1943: 96).

Os estigmas, mesmo que em parte procedentes, de aliancistas dos portugueses e perseguidores de escravos fugidios e destruidores de quilombos não de- 


\section{A abordagem interdisciplinar no estudo do Homo brasilis}

veriam obscurecer a vitalidade empreendida pela linhagem masculina tupi na construção territorial brasileira, que vem a ser o maior espaço nacional contínuo unido por uma única língua já existente. A nosso ver, a espacialidade da América Portuguesa se fez como continuidade e desdobramento do já preexistente expansionismo tupi-guarani, considerado um dos mais expressivos registrados pela arqueologia pré-histórica (cf. Brandão, 1999: 120).

Evidente que os tupis incorporados à sociedade colonial não iriam entregar placidamente suas mulheres e filhas ao deleite sexual de poucos portugueses, sendo por estes excluídos da participação no processo reprodutivo de formação do "branco" do Sudeste. Deste modo, nos parece claro que o registro histórico se contrapõe de forma efetiva à conclusão de Pena a respeito da patrilinhagem indígena.

\section{O histórico do "português" sefaradim}

Não é somente em relação ao indígena que observamos tal desencontro entre os dados genéticos e historiográficos, em relação à linhagem paterna. Esta mesma discrepância nos parece também presente na questão do percentual genético de origem judaica.

Inicialmente, devemos considerar que o Brasil foi destino migratório, em tempos históricos diversos, dos dois principais grupos judaicos. O primeiro a chegar foi o denominado sefardim, ou sefaradim. A maior parte dos historiadores considera este contingente étnico como relacionado aos hebreus do Oriente Médio. Dispersos em razão dos conflitos instaurados na Judeia com as autoridades romanas, principalmente após a destruição do Templo de Salomão em 70 d. C., marco histórico para a Diáspora, grande parte dos hebreus veio a se instalar na Península Ibérica, denominada pelos conquistadores romanos de Hispania. "É o que se pode extrair de registros múltiplos, a exemplo de fontes literárias, crônicas romanas, literatura talmúdica, disposições conciliares cristãs e, sobretudo, restos arqueológicos dispersos pela geografia da península ibérica" (Hermann e Vainfas, 2005: 17).

Contudo, Sand (2011: 27-8) demonstra que os conceitos fundamentais do judaísmo como um ethno que compartilha uma origem única vieram a se formar somente ao final do século XIX e início do XX. Observando que vários reinos se converteram ao judaísmo no final da Antiguidade e início da Idade Média, inclusive no Norte da África, Sand considera que os judeus ibéricos teriam sua origem étnica relacionada não somente aos hebreus dispersos, mas também, e majoritariamente, a tribos berberes judaizadas. Apesar migrarem para a Península Ibérica quando esta foi conquistada pelos árabes, após ali instaladas estas tribos teriam resistido à conversão ao islamismo (Idem: 221-222). 


\section{Renato Pereira Brandão}

Assim, quando da formação do Reino de Portugal no século XII, no âmbito da Reconquista, havia um grande número de judeus estabelecidos nos centros urbanos que seriam integrados a este novo Reino ibérico, como Lisboa, Santarém, Évora, e outros. E como também ocorreu em outros reinos ibéricos, em Portugal os judeus, assim como os islâmicos, tinham suas religiosidades respeitadas.

Porém a situação favorável aos judeus foi, por motivos vários, se deteriorando a partir do século XIII. No final deste século, os judeus já eram alvo de pesadas discriminações e perseguições, principalmente em Castela. A conjuntura se agravou com a união matrimonial dos Reis Católicos, no final do século XV, já que esta desembocou no processo aglutinador de formação do Reino de Espanha e de construção de sua identidade nacional. Esta situação crítica culminou com o estabelecimento do tribunal da Inquisição em 1478. Por último, os Reis Católicos decretaram a expulsão dos judeus da Espanha no ano de 1492. Como consequência, Portugal, único reino ibérico não incorporado ao de Espanha, acabou por ser o principal receptor do contingente judaico.

A incorporação de um grande número de judeus ao seu pequeno reino levou o rei D. João II a tomar medidas contraditórias, mas que tendiam a uma futura acomodação. Por ter anteriormente falecido o príncipe D. Afonso, herdeiro do reino, casado com a filha herdeira dos Reis Católicos, D. Isabel, D. João II foi sucedido por seu primo e cunhado, D. Manuel. Este, desejoso em restabelecer a aliança matrimonial com a Espanha, viu-se obrigado a aceitar a imposição dos Reis Católicos de decretar a expulsão dos judeus de Portugal, o que foi feito em 1497. Contudo, D. Manuel usou de uma série de artifícios para burlar a imposição dos sogros, como, por exemplo, limitar o transporte e portos de saída, estimular o sequestro e conversão de crianças judias, obrigando a maior parte do contingente sefaradim ibérico a aceitar a compulsória conversão ao cristianismo. "Essas medidas draconianas lograram o êxito pretendido e Portugal assistiu à conversão forçada de milhares de judeus que, batizados em pé, deram origem à comunidade de cristãos-novos portugueses”(Idem: 35). Assim, os sefaradim espalhados pela Península Ibérica acabaram, em sua maioria, por se concentrar em Portugal.

A institucionalização dos tribunais de Inquisição no Reino se deu no reinado do sucessor de D. Manuel, D. João III, em 1536, coincidindo com o início da ocupação colonial do Brasil, para onde as primeiras cartas de doação de capitanias hereditárias começaram a ser concedidas pouco antes, em 1534. Neste momento, Portugal, que contava com um dos menores contingentes populacionais da Europa, estava à frente de um imenso império ultramarino, formado por ricos empórios orientais, que sugava de sua terra natal os já poucos portugueses, despovoando o Reino.

Diferente do ocorrido em Portugal, Espanha e América Espanhola, no Brasil não foi instalado o tribunal do Santo Ofício. Não que deixasse de existir a 
perseguição aos cristãos-novos na América portuguesa. Além das Visitações, restritas aos séculos XVI-XVII, posteriormente foi montada uma rede de agentes do Santo Ofício no Brasil, que agiam em articulação com a justiça eclesiástica (cf. Rodrigues, 2009: 2-3). Porém, a ausência do tribunal específico impossibilitou que no Brasil a Inquisição atuasse de forma contundente, tal como na Península Ibérica e na América hispânica. Evidente que esta circunstância, que não nos parece gratuita, acabou por "empurrar" a maior parte do contingente ibérico judaico concentrado em Portugal para o Brasil (cf. Assis e Vainfas, 2005: 47).

Não se tem registros documentais que permitam quantificar o percentual de "cristãos-novos" entre os emigrantes portugueses para o Brasil nos primeiros séculos de colonização. Contudo, estes emigrantes certamente formavam um percentual expressivo e, em alguns lugares, provavelmente seriam maioria. Atestam isto diversos documentos emitidos pelas autoridades da Coroa de Espanha na América, onde os luso-brasileiros, neles registrados unicamente como "portugueses", são identificados como "judaiçantes", "cristianos nuebos" ou "gente poco segura em las cosas de nuestra santa fee Catholica", como presente na Real Célula de 17 de outubro de 1602 (apud Lewin, 1939: 51-52). Clérigos e religiosos hispânicos dos territórios vizinhos da região do Rio da Prata solicitaram por diversas vezes, mas sem sucesso, a instalação do tribunal da Inquisição no Brasil, procurando atingir os paulistas que assaltavam suas missões, por serem estes sabidamente majoritariamente de origem judaica (cf. Fabel, 2008: 140-141). Em 1619, o procurador geral das províncias do Rio da Prata, capitão Manuel de Frias, pediu a instalação do tribunal da Inquisição em Buenos Aires visando atingir, não aos platinos, mas aos "portugueses" que ali entravam, por considerá-los “judaizantes que entravam e saiam das províncias do Peru” (Ceballos, 2007: 137). Canabrava (1984: 157, 161) observa que nas fontes documentais hispânicas é raro encontrar citação de nacionalidade portuguesa sem o complemento de "judeu" ou "judaizante", e que muitos dos judeus portugueses referidos na documentação hispânica deveriam ser, na verdade, judeus brasileiros. Considerando que no período colonial inexistia uma identidade nacional para os brasileiros, identificados documentalmente como "portugueses", por se tratar do século XVII, acreditamos que os judeus brasileiros representariam a quase totalidade dos "judeus portugueses" referidos na documentação hispânica. Ainda em relação ao século XVII, ao observar que a prata, os negros e o açúcar eram os sustentáculos do comércio da América Portuguesa, Salvador (1978: 21) destaca que tais tratos mercantis "deslizavam pela mão de hebreus sefarditas".

Considerando que a América Portuguesa fora dividida em 1621 em dois estados distintos, o Estado do Brasil e o Estado do Maranhão, este englobando a região Norte, esta primeira leva sefaradim foi dirigida quase que exclusivamente ao Estado do Brasil. Esta corrente migratória, instalada no Brasil sob a égide de "cristãos-novos", tem como característica a diversidade de ofícios e ocupações, 


\section{Renato Pereira Brandão}

englobando desde artesãos e pequenos lavradores a poderosos mercadores, senhores de engenho e traficantes de escravos. Outra característica peculiar, que a difere de outras correntes migratórias judaicas, é o caráter miscigenatório aqui adquirido, tanto do contingente masculino como feminino, já que "chegavam muitas vezes em famílias, à diferença migratória portuguesa, essencialmente masculina" (Assis e Vainfas, 2005: 47). Estas características, aliadas ao temor aos agentes do Santo Ofício, fizeram com que, ao longo do tempo, este primeiro contingente sefaradim perdesse sua identidade étnica e religiosa e constituísse, em contrapartida, um dos principais elementos formadores do segmento "branco" da sociedade colonial brasileira.

Conforme corretamente registrado por Pena (2002: 22), posteriormente, nos séculos XIX-XX, houve outra leva migratória sefaradim, originária da África do Norte, principalmente Tanger e Marrocos. Contudo, esta não irá se estabelecer nos antigos domínios do Estado do Brasil, e sim do Maranhão e Grão-Pará. Dispersada inicialmente pelas pequenas cidades do Pará e Amazonas, com a decadência do ciclo da borracha acabaram por se estabelecer nas capitais, originando as atuais comunidades judaicas de Belém e Manaus, havendo também uma pequena coletividade no Amapá (cf. Cytrynowicz, 2010).

O outro contingente judaico, diferenciado do sefaradim, tem a denominação de ashkenazim ou asquenazim. Sua origem remete também à Diáspora do século I, quando um grupo minoritário preferiu migrar para fora dos limites do Império Romano. Estabelecido na Europa Centro Oriental, o grupo converteu ao judaísmo alguns bárbaros, principalmente germânicos e eslavos. Sua língua original, o iídiche, é uma variante de um idioma germânico arcaico. A primeira grande onda migratória de judeus asquenazim para o Brasil se deu somente no início do século XX, no período de 1904 a 1914, patrocinada pela Jewish Colonization Association, organização fun dada pelo Barão Maurice de Hirsch com a finalidade de transferir para Argentina e Brasil levas de judeus do Leste europeu, principalmente Rússia e Ucrânia. Posteriormente, houve mais três ondas migratórias no século XX, a última na década de 1950, decorrentes das conturbações políticas e perseguições étnicas que assaltaram a Europa, principalmente a Alemanha (Pitlivk, 2010: 1-3).

Quanto à identificação da herança genética judaica, esta se encontra associada ao haplogrupo 9, por apresentar "frequências máximas em judeus e em outras populações do Oriente Médio, embora seja visto também no Mediterrâneo" (Pena, 2002: 21). Apesar de Pena não especificar se o contingente judaico referido seria o sefaradim ou o asquenazim, a associação ao primeiro nos parece óbvia, por ter o haplogrupo 9 frequência maior no Oriente Médio.

O percentual médio deste haplogrupo presente no "branco" brasileiro atual é de $8 \%$, enquanto que o encontrado em Portugal é de 6,5\%. Pena considera esta diferença como coerente com os registros históricos da migração para o Bra- 
sil dos cristãos-novos portugueses. Discordamos, por considerar que a diferença de somente $2 \%$ não se coaduna com o quadro histórico apresentado. Contudo, a questão torna-se mais expressiva ao se considerar que o percentual apresentado para a região Nordeste, principal receptora do fluxo migratório sefaradim em tempos coloniais, é de apenas $2 \%$, número expressivamente baixo e abaixo do percentual apresentado no genoma masculino português atual. Evidentemente, há inteiro descompasso entre o apresentado pela genética e pela história.

Pela tabela apresentada por Pena, nota-se também que o percentual médio do citado haplogrupo só é representativo para o Brasil devido ao elevado valor encontrado para a região Norte, de 16,3\%. Pena justifica a discrepância ao "descobrimos que, no início do século XIX, houve uma significativa imigração de judeus marroquinos para a Amazônia" (Pena, 2002: 22). Contudo, é preciso considerar ainda que, a partir da época citada e o início do século XX, a região Norte foi recebedora de levas migratórias de sírios e libaneses bem mais expressivas do que a dos judeus marroquinos. Estes, apesar de identificados como árabes ou turcos, não eram originários da Península Arábica nem da Turquia, e sim do Oriente Médio, portanto igualmente associados ao haplogrupo 9 , o que melhor justificaria, a nosso ver, o elevado percentual apresentado para este haplo-grupo.

$\mathrm{O}$ caso dos judeus marroquinos nos remete à consideração de Sand de que o contingente judaico do norte da África seja de origem autóctone, e não decorrente de migração originária do Oriente Médio. Neste caso, o haplogrupo identificador da linhagem patrilinear judaica sefaradim seria não mais o 9 , mas sim o PN2. Considerando este como referencial para a identificação do "cristão-novo", apesar de sua presença e dispersão em outros contingentes étnicos, constata-se que o percentual médio apresentado, $10 \%$, é praticamente o mesmo para Portugal, de 9,7\%. Assim, mesmo considerando o haplogrupo PN2 como referencial para o contingente sefaradim, encontramos expressa discrepância entre dados filogenéticos e registros históricos.

\section{A razão do desencontro entre a genética e a história no caso da patrilinhagem}

Acreditamos que a razão deste desencontro está no fato de que Pena, ao projetar para a história os resultados obtidos pela genética, não diferenciou corretamente os dados obtidos tanto referentes à matrilinhagem quanto à patrilinhagem. Como no primeiro caso a carga genética do DNA mitocondrial é transmitida pela mãe tanto para filhas como para filhos, uma mulher transmitirá a carga genética recebida por suas avós, tanto materna quanto paterna. Neste caso, haverá a permanência do marcador genético, mesmo que o processo miscigenatório original tenha ocorrido em tempo muito distante. 


\section{Renato Pereira Brandão}

Contudo, de outro modo se dá o registro da patrilinhagem. Neste, o fato de que o processo ocorre unicamente na linhagem masculina, faz com que o registro genético se perca para os indivíduos que tiveram somente filhas, ou quando somente estas teriam atingido a fase reprodutiva. Assim, o indivíduo recebe a carga filogenética somente de seu avô paterno, sendo excluída aquela referente ao avô materno. Esta distorção torna-se menor em um contingente populacional estável, pouco recebedor de correntes migratórias diversas e em tempos diversos. Porém não é este o caso do Brasil.

Por esta razão, os registros dos processos miscigenatórios mais antigos tendem a diluir, ou mesmo desaparecer, frente aos mais recentes, em função da possibilidade da quebra da sequência patrilinear. Como a incorporação da população indígena, tanto feminina como masculina, se deu mais intensamente, no caso do Sudeste quase que exclusivamente nos séculos XVI e XVII, no percurso reprodutivo até o século XXI diversas destas sequências patrilineares foram, em algum momento, irreversivelmente quebradas.

O mesmo ocorre em relação à ancestralidade paterna judaica sefaradim. Assim como ocorrido com a indígena, seu registro foi sendo diluído ao longo do tempo, já que a sua incorporação miscigenatória no conjunto populacional "branco" brasileiro do Nordeste e Sudeste se deu primordialmente nos dois primeiros séculos coloniais.

Por outro lado, em referência à região Norte, onde o percentual encontrado para o haplogrupo 9 é de 16,3\%, observa-se uma coerência entre os dados fornecidos pela genética e pela história, pois neste caso a imigração "árabe" para a região amazônica se deu em tempos mais recentes, séculos XIX-XX, o que faz seu registro se expressar de forma mais intensa.

Como também a emigração portuguesa para o Brasil se deu com mais intensidade, não em tempos coloniais, mas a partir do início do século XX, é de se esperar que não haja diferenças significativas nas frequências dos haplogrupos em brasileiros e portugueses, conforme observado por Pena.

Ainda em outros artigos que formam a obra Homo brasilis identificamos passagens que apontam para a necessidade de cautela na projeção histórica dos dados filogenéticos masculinos. No artigo "A história do povoamento pré-colombiano das Américas e o cromossoma Y humano", Santos e Tarazona-Santos nos mostram resultados diferentes para as linhagens maternas e paternas para a ocupação aborígene da América. Enquanto os resultados obtidos pelas análises do DNA mitocondrial de ameríndio apontam para a diversidade de ondas migratórias (4 para o grupo de Torrini e Wallace) de identidade asiática, os resultados da análise do cromossoma $\mathrm{Y}$ identificam somente uma ancestralidade patrilinear exclusivamente americana. A partir destes dados, os autores sustentam que "nos estudos com DNA mitocondrial e Y, mesmo que não tenham sido utili- 
A abordagem interdisciplinar no estudo do Homo brasilis

zadas as mesmas amostras nem as mesmas populações, não é surpreendente que as linhagens maternas e paternas possam ter histórias ou origens geográficas diversas" (Santos e Tarazona-Santos, 2002: 52). Contudo, não vemos como formular uma hipótese social migratória, balizada por referenciais etnográficos, conciliatória de dados tão discrepantes. Além do mais, tanto os dados arqueológicos quanto linguísticos têm afinidades unicamente com os resultados referentes à matrilinhagem, ou seja, confirmando a ocorrência de, pelo menos, quatro grandes levas migratórias de origem asiática. Certamente, os autores estão sujeitos à mesma crítica metodológica apontada em Pena. A única onda migratória registrada no referencial patrilinear se refere exclusivamente à última e mais recente leva migratória (cf. Prado e Alves-Silva, 2002: 69).

\section{Considerações finais}

Incontestavelmente, é bem-sucedida a proposta de Pena de utilizar dados filogenéticos para demonstrar que é de todo improcedente procurar estabelecer qualquer categorização de cunho étnico-biológico, ou racial, para o povo brasileiro, por ser este originário de um intenso e aglutinante processo miscigenatório.

Os resultados obtidos a partir dos estudos da linhagem mitocondrial do "branco" brasileiro expressam o sucesso de seu objetivo. Neste contexto, destacam-se os resultados obtidos para o Sudeste por apresentarem um surpreendente equilíbrio proporcional entre os contributos étnicos de origens europeias, africanas e indígenas.

Nossa crítica se volta, primordialmente, para a apropriação histórica dos dados filogenéticos referentes à patrilinhagem do Sudeste, tendo como objetivo demonstrar que os valores apresentados pela genética para a linhagem masculina são distorcidos em sua intensidade pela temporalidade. A partir desta constatação, estendemos nossa crítica à perspectiva metodológica adotada por Pena por considerar que sua proposta de abordagem interdisciplinar expressa um determinismo e uma hierarquização acadêmica inadequada, ao delegar à genética a capacidade, não de contribuir, mas de reconstruir a história, conforme explicitamente expresso (Pena, 2002: 12).

Inicialmente, devemos destacar que toda a atual produção acadêmica tem como escopo a permanente reformulação dos modelos hipotéticos propostos, ou seja, nenhum conhecimento científico deverá advogar formas de verdades absolutas, conforme nos remete a ideia de reconstrução. Através do modelo hipotético-dedutivo procuramos, não a identificação de falsidades e verdades, mas o estabelecimento de uma hipótese interpretativa de modo a ser possível o seu desenvolvimento. Apesar de Pena usar com frequência o termo "sugere" ao tratar das frequências estatísticas dos indicadores genéticos, os dados colhidos 


\section{Renato Pereira Brandão}

pelas análises são tratados como informações determinantes, e não como construtores de modelos hipotéticos passíveis de reformulações.

É preciso ainda lembrar que a barreira entre a história e a pré-história é meramente conceitual, inexistindo em uma perspectiva processual. Esta percepção é imprescindível ao lidar com a nossa historiografia colonial, onde se cruzam diversas etnias que já se diferenciam dentro do conjunto maior onde estão agrupadas, como nativas, europeias, africanas e asiáticas. A chegada do europeu não significou o findar do histórico dos nossos indígenas, mesmo os litorâneos, mas sim um novo direcionamento de um processo histórico já em curso. Sabemos que em cerca de $500 \mathrm{~d}$. C. os tupi litorâneos ocupavam quase toda nossa extensa faixa litorânea. Contudo, anteriormente, esta região não estava desocupada. Não sabemos ao certo como se deu esta sucessão, se por deslocamento ou miscigenação. Considerando que os guarani não têm nenhuma intimidade com o ambiente marinho ou habilidade canoeira, é provável que a miscigenação e transculturação tenham tido expressão neste processo de contato interétnico. Na região litorânea do Norte Fluminense havia um bolsão onde os tupi não conseguiram penetrar, em domínio da etnia goitacá. Os registros que temos de cronistas e jesuítas sobre a expressão do fenótipo goitacá, assim como de seu complexo cultural, em muito se diferenciam das descrições não só dos tupi, mas, inclusive, do predominante estereótipo asiático. Inicialmente isolados, tupi e goitacá acabaram por se miscigenar em alguns aldeamentos jesuíticos fluminenses. Estes, por sua vez, com o acréscimo de contingentes populacionais descendentes de europeus e africanos, vieram a originar núcleos urbanos atuais, como no caso do município de São Pedro da Aldeia.

Temos assim um quadro de grande diversidade étnica e complexidade cultural que, independentemente da contradição apontada, nos leva a considerar questionável acreditar que a identificação do percentual do haplogrupo 18 nas populações atuais seria um dado determinante e definitivo no elaborar da história da relação índio/europeu na América Portuguesa.

Devemos ainda considerar que o citado haplogrupo 18 é utilizado como referencial por estar presente em um percentual de aproximadamente $80 \%$ nas atuais populações ameríndias. Contudo, não nos é apresentada sua variabilidade dentro deste diversificado e extenso conjunto étnico genericamente denominado ameríndio. Assim, independentemente da diferenciação em relação ao registro matrilinear, consideramos questionável a utilização deste referencial, especialmente com relação ao caso citado, por não se ter como saber o percentual de incidência deste registro genético na primeira população a ocupar o litoral, na tupi litorânea e na goitacá.

Considerando ainda que uma versão histórica divulgada para a formação de um povo e sua nação não é unicamente um relato ilustrativo, mas um mito com fortes influências nas construções de identidades nacionais e culturais, te- 
mos o temor de que o equívoco interpretativo relativo à patrilinhagem possa vir a reforçar, mesmo que oculto pelo viés da crítica à opressão colonial, um estereótipo eurocêntrico, apesar de não ser expressamente esta a intenção do autor.

Consideramos, por fim, que as pesquisas apresentadas trazem inestimáveis contributos ao complexo estudo da formação étnica da população brasileira. Contudo, por ser este um campo de estudo interdisciplinar, envolvendo primordialmente a biologia, a antropologia cultural e a história, reivindicamos maior interação entre os pesquisadores das áreas envolvidas.

\section{Anexo}

Percentagem de indivíduos observados em cada haplogrupo do cromossomo Y, em brasileiros e portugueses. Os haplogrupos estão ordenados por ordem decrescente de frequência nos brasileiros

\begin{tabular}{lrrrrrr}
\hline \multirow{2}{*}{ Haplogrupo } & \multicolumn{5}{c}{ Região do Brasil } & \multirow{2}{*}{ Portugal } \\
\cline { 2 - 5 } 1 & $\mathrm{~N}$ & $\mathrm{NE}$ & $\mathrm{S}$ & $\mathrm{SE}$ & Total & \\
\hline 1 & 53,1 & 65,3 & 42,3 & 56,0 & 54,0 & 63,4 \\
2 & 12,2 & 18,4 & 28,8 & 12,0 & 18,0 & 12,9 \\
PN2 & 10,2 & 8,2 & 9,6 & 12,0 & 10,0 & 9,7 \\
9 & 16,3 & 2,0 & 3,8 & 10,0 & 8,0 & 6,5 \\
3 & 2,0 & 2,0 & 9,6 & 0,0 & 3,5 & 2,2 \\
M34 & 2,0 & 0,0 & 5,8 & 4,0 & 3,0 & 2,2 \\
8 & 0,0 & 4,1 & 0,0 & 4,0 & 2,0 & 1,1 \\
22 & 0,0 & 0,0 & 0,0 & 2,0 & 0,5 & 2,2 \\
AF & 2,0 & 0,0 & 0,0 & 0,0 & 0,5 & 0,0 \\
20 & 2,0 & 0,0 & 0,0 & 0,0 & 0,5 & 0,0 \\
EA & 0,0 & 0,0 & 0,0 & 0,0 & 0,0 & 0,0 \\
18 & 0,0 & 0,0 & 0,0 & 0,0 & 0,0 & 0,0 \\
Número de indivíduos & 49 & 49 & 52 & 50 & 200 & 93 \\
\hline
\end{tabular}

Fonte: In Pena (2002: 20). 
ASSIS, Angelo A. F. e VAINFAS, Ronaldo. A esnoga da Bahia: cristãos-novos e criptojudaísmo no Brasil quinhentista. In: GRINBERG, Keila (org.). Os judeus no Brasil: inquisição, imigração e identidade. Rio de Janeiro: Civilização Brasileira, 2005, p. 43-64.

BRANDÃO, Renato Pereira. A espacialidade missioneira jesuítica no Brasil colonial. In: A forma e a imagem: arte e arquitetura jesuítica no Rio de Faneiro colonial. Rio de Janeiro: PUC-Rio, 1991.

- A cruz de Cristo na Terra de Santa Cruz: a geopolítica dos descobrimentos e o domínio estratégico do Atlântico sul. Tese (Doutorado). Niterói: Universidade Federal Fluminense, Centro de Estudos Gerais/ICHF, 1999.

A Companhia, Gusmão e Pombal: do Tratado de Madri à expulsão do Império. Revista do Instituto Histórico e Geográfico Brasileiro. Rio de Janeiro: IHGB, 170 A (443), abr./jun. 2009, p. 21-56.

CANABRAVA, Alice Piffer. O comércio português no Rio da Prata: 1580-1640. Belo Horizonte: Itatiaia/São Paulo: Edusp, 1984.

CEBALLOS, Rodrigo. Arribadas portuguesas: a participação luso-brasileira na constituição social de Buenos-Aires (c. 1580-1650). Tese (Doutorado). Niterói, Universidade Federal Fluminense, Instituto de Ciências Humanas e Filosofia, 2007.

CORTESÃO, Jaime. Introdução à história das bandeiras. Lisboa: Portugália, 1964

CYTRYNOWICZ, Roney (2010). História da comunidade judaica do Amazonas. Disponível em http://www.conib.org.br/ comunidades. ASP. Acesso em dezembro de 2011.
FABEL, Nachman. Fudeus no Brasil. São Paulo: Humanitas/ Edusp, 2008.

HERMANN, Jaqueline e VAINFAS, Ronaldo. Judeus e conversos na Ibéria no século XV: sefardismo, heresia, messianismo. In: GRINBERG, Keila (org.). Os judeus no Brasil: inquisição, imigração e identidade. Rio de Janeiro: Civilização Brasileira, 2005, p. 15-42.

LEWIN, Boleslao. El judio en la epoca colonial. Buenos Aires: Ed. Colégios de Estudos Superiores, 1939.

LIVRO PRIMEIRO DO GOVERNO DO BRASIL - 1607/1633. Rio de Janeiro: Ministério das Relações Exteriores, 1958.

NAVARRO, Azpilcueta e outros. Cartas avulsas 1550-1568. Belo Horizonte: Itatiaia/ São Paulo: Ed. da Universidade de São Paulo, 1988.

PENA, Sérgio D. J. et al. Retrato molecular do Brasil. Ciência Hoje. São Paulo: SPBC, (27), 2000.

Retrato molecular do Brasil, versão 2001. In: Homo brasilis: aspectos genéticos, linguísticos, históricos e socioantropológicos $d a$ formação do povo brasileiro. Ribeirão Preto: Funpec, 2002, p. 11-28.

PITLIVK, Marcio. Do leste europeu ao Brasil (2010). Revista Morashá (eletrônica) $\mathrm{n}^{\circ}$ 70. Disponível em http://www.morasha. com.br/edicoes/ed70.asp. Acesso em dezembro de 2010.

PORTO, Aurélio. História das missões orientais do Uruguai. Rio de Janeiro: SPHAN/ MES, 1943.

PRADO, Vania F. e ALVES-SILVA, Juliana. Linhagens mitocondriais em populações nativas das Americas. In: Homo brasilis: aspectos genéticos, linguísticos, históricos e 
socioantropológicos da formação do povo brasileiro. Ribeirão Preto: Funpec, 2002, p. 42-72.

RODRIGUES, Aldair Carlos. Formação e atuação da rede de comissários do Santo Ofício em Minas colonial. Revista Brasileira de História, v. 29, (57), 2009, p. 145-164.

SALVADOR, José Gonçalves. Os cristãosnovos e o comércio no Atlântico Meridional: com enfoque nas capitanias do Sul, 1530-1680. São Paulo: Pioneiras/ Brasília: INL, 1978.

SAND, Shlomo. La invención del pueblo judio. Madri: Akal, 2011.

SANTOS Fabrício R. e TARAZONASANTOS, Eduardo. A história do povoa- mento pré-colombiano das Américas e o cromossoma Y humano. In: Homo brasilis: aspectos genéticos, linguísticos, históricos e socioantropológicos da formação do povo brasileiro. Ribeirão Preto: Funpec, 2002, p. 41-61.

SILVA, Raul de Andrade e. São Paulo nos tempos coloniais. Revista de História. São Paulo: Fac. de Filosofia da USP, v. 10 (21-22), 1955, p. 55-88.

SOUSA, Gabriel de. Tratado descritivo do Brasil em 1587, $3^{\text {a }}$ ed. São Paulo: Comp. Ed. Nacional, 1938.

\section{Resumo}

Neste artigo, temos o objetivo de confrontar os registros históricos e interpretações historiográficas referentes às ancestralidades indígena e judaica na formação populacional da região Sudeste brasileira com os resultados obtidos pelo geneticista Sérgio Pena em suas pesquisas sobre a origem filogenética do segmento da população brasileira autoclassificada como "branca". Nosso trabalho compara os resultados apresentados por Pena na obra Homo brasilis com dados históricos originados não só de fontes bibliográficas, mas também de fontes documentais. Concluímos que os dados filogenéticos para a ancestralidade matrilinear apresentados por Pena coincidem com os dados históricos, havendo, porém, discrepância quanto à ancestralidade patrilinear.

Palavras-chave: Homo brasilis; genética; história; ancestralidade; indígena; sefaradim.

\section{Abstract \\ This paper intends to compare historical records and interpretations about Indian and Jew ancestry in the origin of Brazilian South-East population with the results of the geneticist Sérgio Pena in his study of the filogenetic origins of the segment of Brazilian population self-classified as "white". We compare Pena's outcomes in his work Homo brasilis with historical data deriving from}




\section{Renato Pereira Brandão}

bibliographical material and documents, and conclude that Pena's outcomes match the historical data in the case of matrilineal ancestry, but are discrepant in the case of pratrilineal ancestry.

Keywords: Homo brasilis; genetics; history; ancestry; indigenous; Sephardic.

\section{Résumé}

Cet article veut comparer des documents historiques et des interprétations historiographiques concernant les ascendances indigène et juive dans la formation de la population de la région Sud-Est du Brésil avec les résultats obtenus par le généticien Sérgio Pena dans sa recherche sur l'origine phylogénétique de la partie de la population brésilienne autoclassifiée comme «blanche». Nous comparons ainsi les résultats présentés par Pena dans l'oeuvre Homo brasilis à des données historiques provenant de sources bibliographiques et documentales, et nous concluons que les données phylogénétiques concernant l'ascendance matrilinéaire coïncident avec les données historiques, mais qu'il y a un désaccord dans le cas de l'ascendance patrilinéaire.

Mots-clés: génétique; histoire; ascendance; indigènes; séfarades. 